\title{
Enhancement of Groundnut Production through Front Line Demonstration
}

\author{
Khumlo Levish Chongloi ${ }^{1 *}$, Deepak Singh ${ }^{1}$ and I. Meghachandra Singh ${ }^{2}$ \\ ${ }^{1}$ ICAR-Krishi Vigyan Kendra, Chandel, India \\ ${ }^{2}$ ICAR Research Complex for NEH Region, Manipur Centre, Lamphelpat, Imphal, India \\ *Corresponding author
}

\section{A B S T R A C T}

\begin{tabular}{l} 
K e y w o r d s \\
Yield gap; \\
Technology gap, \\
Extension gap, \\
Technology index, \\
Frontline \\
demonstration \\
\hline Article Info \\
\hline $\begin{array}{l}\text { Accepted: } \\
\text { 18 November } 2020 \\
\text { Available Online: } \\
\text { 10 December } 2020\end{array}$ \\
\hline
\end{tabular}

Front line demonstration is one of the important tools for transfer of technology. The present front line demonstration was carried out by Krishi Vigyan Kendra, Chandel, ICAR-Manipur Centre to find out yield gaps between demonstration practices under Front Line Demonstration and farmer's practice of kharif groundnut in 29 ha. in different villages during 2007-08 to 2013-14, respectively. The result indicated that average seed yield of groundnut in demonstration practices ranged between 12.55 and $24.50 \mathrm{q} / \mathrm{ha}$ whereas in Farmers practices it was 8.58 to $13.80 \mathrm{q} /$ ha during demonstrated years. The per cent increased in yield with demonstration Practices over Farmer Practices was ranged between 31.63 and 46.12. The technological and extension gap were from 5.50 to 17.45 and from 3.97 to $11.30 \mathrm{q} /$ ha respectively. Similarly, technological index were decrease from 58.17 to 18.33 per cent during the study period. The benefit cost ratio was 1.82 to 3.82 under demonstration, while it was 1.36 to 2.27 under farmer practices. By conducting front line demonstration on improved practices with HYV of proven technologies in farmer's field, yield potential of groundnut enhanced to a great extent which increased in the income level of farmers and improved livelihood of farming community.

\section{Introduction}

India is one of the largest producers of oilseeds in the world and occupies an important position in the Indian agricultural economy. Among the oilseed crops groundnut is one of the most important being grown in 11 states in an area of 4.19 million ha with a production of 5.62 million tonnes of pods per annum. The average productivity of groundnut in India (1341 $\left.\mathrm{kg} \mathrm{ha}{ }^{-1}\right)$ is comparable to world average (Anonymous, 2013). Groundnut is called as the 'King' of oilseeds. It is one of the most important food and cash crops of our country. Groundnut, popularly known as the peanut is a leguminous crop cultivated for edible purposes. It is found exclusively in tropical and subtropical regions of the world. It is sometimes considered as a grain legume because the seed can produce oil and the crop is categorized as an oil crop. The oil content in the seed is estimated to be around $44-50 \%$. The useful part or the part of economic importance within the crop grows under the ground as pods. While being a valuable 
source of all the nutrients, it is a low priced commodity. Groundnut is also called as wonder nut and poor men's cashew nut and is one of the most important cash crops of our country though being a low-priced commodity but a valuable source of all the nutrients.

Groundnut is gaining an importance in Chandel district of Manipur, as drought is one of the major problems during kharif season. Groundnut is raised mostly as a rainfed kharif crop, being sown from May to June, depending on the monsoon rains. The farmers mainly depend on rain for their crop cultivation. Due to lack of irrigation facilities and poor alternative cropping pattern in rain fed areas like Chandel districts the farmers have been adopted to cultivating groundnut crop after the interventions by KVK Chandel, ICAR-Manipur Centre.

Chandel district of Manipur has a sizeable area under groundnut cultivation however, with the available improved technologies, it is possible to bridge the yield gap and increase the productivity up to the potential level (25.0 $\mathrm{q} /$ ha to $35 \mathrm{q} / \mathrm{ha}$ ). The reasons for low productivity are poor knowledge about newly introduced crop production and protection technologies and their management practices in the farmer's field. KVK, Chandel has conducted various FLDs on groundnut using high yielding variety ICGS-76 with the objectives of showing the production potential of the new production technologies under actual farm situation. Keeping the above points in view, the present study was undertaken to find out the effects of FLDs on bridging the yield gap in terms of technology gap, extension gap and technology index (Table 1).

\section{Materials and Methods}

The study was carried out by KVK Chandel during Kharif2007-08, 2008-09, 2009-10,
2010-11, 2011-12, 2012-13 and 2013-14 in the farmer's for 29 hectares of land. During these seven years of FLDs, an area of 29 ha was covered involving 74 practicing farmers. Scientific package of practices like line sowing, nutrient management, seed treatment and whole package were used in the demonstrations and groundnut seed variety ICGS-76 was taken under FLD. In general, soils of the area under study were clay loam and medium to low in fertility status.

The seeds of groundnut were sown to ensure recommended plant spacing within a row because excess population adversely affects growth and yield of crop. Sowing was done in the first week of May to first week of June with a seed rate of $100 \mathrm{~kg} / \mathrm{ha}$. The yield data from both the demonstration and farmers practice were recorded and their technology gap, extension gap and the technology index were worked out using methods developed by Samui et al., (2000) as stated below:

Tech. gap $=$ Potential yield - Demo. Plot yield

Ext. gap $=$ Demo. Plot yield - Farmer's plot yield

$$
\text { Technology index }=\underline{\mathrm{Pi}-\mathrm{Di}} \times 100
$$

$$
\mathrm{Pi}
$$

Where

$\mathrm{Pi}=$ Potential yield $; \mathrm{Di}=$ Demonstration yield

\section{Results and Discussion}

Results of 74 nos. of FLDs conducted during 2007-08 to 2013-14 in 29 ha area on farmer's field of Chandel district indicated that the yield of groundnut var ICGS-76 was substantially higher than the variety grown by the farmers during all the seven years (Table 2). The yield of groundnut in different 
demonstration plots ranged between 12.55 to $24.50 \mathrm{q} / \mathrm{ha}$ over the study period which was 21.77 to 58.17 per cent higher over farmer's variety. On an average 38.03 per cent increase in yield was obtained in the demonstration plots whereas average yield in farmer's field was recorded only $11.01 \mathrm{q} / \mathrm{ha}$. The maximum yield in demonstration plots was recorded $(24.50 \mathrm{q} / \mathrm{ha})$ during 2012-13 and minimum yield of $12.55 \mathrm{q} / \mathrm{ha}$ was recorded in the year 2007-08. These results are in conformity with the findings of Ratan Lal Solanki and K.C. Nagar. (2020). The poor productivity in farmers practice might be mainly due to factors like use of non-descript local variety, late sowing and low level of agronomic management in addition to non-availability of resources in time.

The result clearly depicts the positive effects of FLDs over the existing practices towards enhancing the yield of groundnut in Chandel district. The technology gap were 17.45, $12.56,13.77,12.15,11.90,5.50$ and $6.53 \mathrm{q} / \mathrm{ha}$ during 2007-08, 2008-09, 2009-10, 2010-11, 2011-12, 2012-13 and 2013-14, respectively. The average technology gap was recorded $7.58 \mathrm{q} / \mathrm{ha}$ during the period of study. The technology gap ranging between 5.50 and $17.47 \mathrm{q} /$ ha reflected the farmer's participation in conducting FLDs.

Table.1 Comparison of demonstration package and farmers practices under FLD on Groundnut

\begin{tabular}{|l|l|l|}
\hline Particulars & Demonstration & Farmers practice \\
\hline Variety & ICGS-76 & Local \\
\hline Time of sowing & $1^{\text {st }}$ week of May to $1^{\text {st }}$ week of June & $2^{\text {nd }}$ week of June to $1^{\text {st }}$ week of Aug. \\
\hline Seed rate & $100 \mathrm{~kg}$ & $150 \mathrm{~kg}$ \\
\hline Fertilizer dose (NPK) & $20: 60: 40 \mathrm{~kg} \mathrm{~N}: \mathrm{P}: \mathrm{K}$ per ha. & No scientific package of practices \\
\hline Plant protection & Need based application & No plant protection \\
\hline Interculrure & Two weeding at 30-35 DAS & One weeding \\
\hline
\end{tabular}

Table.2 Productivity, technology gap, extension gap and technology index in groundnut var.ICGS-76 under FLDs

\begin{tabular}{|c|c|c|c|c|c|c|c|c|c|c|c|c|}
\hline \multirow[t]{2}{*}{ Year } & \multirow[t]{2}{*}{ Area } & \multirow{2}{*}{$\begin{array}{l}\text { No. of } \\
\text { farmers }\end{array}$} & \multirow{2}{*}{$\begin{array}{l}\text { No. of } \\
\text { demo }\end{array}$} & \multicolumn{3}{|c|}{ Seed Yield(q/ha) } & \multirow{2}{*}{$\begin{array}{c}\% \\
\text { increase } \\
\text { over } \\
\text { control }\end{array}$} & \multirow{2}{*}{$\begin{array}{l}\text { Tech } \\
\text { gap } \\
\text { (q/ha) }\end{array}$} & \multirow{2}{*}{$\begin{array}{l}\text { Ext. } \\
\text { gap } \\
\text { (q/ha) }\end{array}$} & \multirow{2}{*}{$\begin{array}{c}\text { Tech. } \\
\text { index } \\
\%\end{array}$} & \multicolumn{2}{|c|}{ B:C ratio } \\
\hline & & & & $\mathbf{P}$ & D & FP & & & & & D & $\mathbf{F P}$ \\
\hline 2007-08 & 2 & 8 & 8 & $25-35$ & 12.55 & 8.58 & 31.63 & 17.45 & 3.97 & 58.17 & 1.82 & 1.36 \\
\hline 2008-09 & 3 & 10 & 10 & $25-35$ & 17.44 & 9.54 & 45.29 & 12.56 & 7.90 & 41.87 & 2.56 & 1.51 \\
\hline 2009-10 & 2 & 7 & 7 & $25-35$ & 16.23 & 9.84 & 39.37 & 13.77 & 6.39 & 45.90 & 2.36 & 1.56 \\
\hline 2010-11 & 5 & 12 & 12 & $25-35$ & 17.85 & 10.58 & 40.72 & 12.15 & 7.27 & 40.50 & 2.59 & 1.68 \\
\hline 2011-12 & 5 & 13 & 13 & $25-35$ & 18.10 & 11.55 & 36.55 & 11.90 & 6.55 & 39.67 & 2.82 & 1.90 \\
\hline 2012-13 & 5 & 13 & 13 & $25-35$ & 24.50 & 13.20 & 46.12 & 5.50 & 11.30 & 18.33 & 3.82 & 2.17 \\
\hline 2013-14 & 7 & 11 & 11 & $25-35$ & 23.47 & 13.80 & 41.20 & 6.53 & 9.67 & 21.77 & 3.66 & 2.27 \\
\hline Total & 29 & 74 & 74 & - & 130.14 & 77.09 & - & & & & & \\
\hline Mean & & & & & 18.59 & 11.01 & 40.13 & 11.41 & 7.58 & 38.03 & 2.80 & 1.77 \\
\hline
\end{tabular}

$\mathrm{P}=$ Potential $\mathrm{D}=$ Demonstration $\mathrm{FP}=$ Farmers' practice

The variation in technology gap observed might be due to dissimilarity in soil fertility and management factors. Benefit Cost ratio was recorded higher (1.82 to 3.82$)$ under demonstration plots compared to farmer's plot (1.36 to 2.27) in all the year of study. Hence, 
higher $\mathrm{B}: \mathrm{C}$ ratios proved economic viability of the interventions made under FLD. Similar finding were reported by Samui et al., (2000).

Therefore, to exploit the potential of improved production and protection technologies efforts through FLDs ought to be increase awareness among the farmers. The extension gap ranging between 3.97 and $11.30 \mathrm{q} / \mathrm{ha}$ during the period of study emphasizes the need to educate the farmer through various means for adoption of improved agricultural production to reverse the trend of wide extension gap. To increase the productivity and production of groundnut, seed replacement of non-descriptive varieties by HYVs is very much essential.

In this context, front line demonstrations are playing an important role in popularizing the HYV of groundnut in the study area. The present study indicated reduction in technology index from 58.17 per cent during 2007-08 to 18.33 percent during 2012-13 which exhibited the feasibility of demonstrated technology in the study areas (Table 2).

The lower value of technology index, the more is the feasibility of technology. As such fluctuation in technology index (ranging between 18.33-58.17 per cent)during the study period in certain villages, might be attributed to the dissimilarity in soil fertility status, weather conditions, non-availability of irrigation water and insect pest attack in the crop. Similar finding were reported by Ahmed et al., (2017)who opined that lower the value of technology index, more is the feasibility of the technology demonstrated.
It may be concluded that the frontline demonstrations conducted on groundnut at the farmers' field revealed that the adoption of improved technologies significantly increased the yield as well as can reduce the technology gap to a considerable extent thus leading to increased productivity of groundnut in the district. Hence, there is a need to disseminate the improved technologies among the farmers with effective extension methods like training and demonstrations. The farmers' should be encouraged to adopt the recommended package of practices including HYV to revert the trend of wide extension gap and for realizing higher returns.

\section{References}

Ahmed, P., Nath, R.K., Sarmah, A.C. and Deka, P.C. (2017). Yield Gap Analysis of Toria (Brassica campestris) in Tinsukia District of Assam. Indian Res. J. Ext. Edu. 17(3).

Anonymous, (2013), Directorate of Economics and Statistics, Govt. of Karnataka GOI (2008) Economic Survey of India 2008, Government of India, New Delhi.

Ratan Lal Solanki and K.C. Nagar.(2020). Yield and Gap Analysis of Groundnut (Arachis hypogaea L.). Productivity through Frontline Demonstration in District Chittorgarh of Rajasthan, India. Int. J. Curr. Microbiol. App. Sci. 9(6): 41194125

Samui, S.K, Maitra, S., Roy, D.K., Mandal, A.K. and Saha, D. (2000). Evaluation of front line demonstration on groundnut. $J$. Indian Soc. Coastal Agri. Res., 18 (2): 180-183.

\section{How to cite this article:}

Khumlo Levish Chongloi, Deepak Singh and Meghachandra Singh, I. 2020. Enhancement of Groundnut Production through Front Line Demonstration. Int.J.Curr.Microbiol.App.Sci. 9(12): 2773-2776. doi: https://doi.org/10.20546/ijcmas.2020.912.330 